\title{
Synthesis
}

\section{Promoting Health and Well-Being by Managing for Social-Ecological Resilience: the Potential of Integrating Ecohealth and Water Resources Management Approaches}

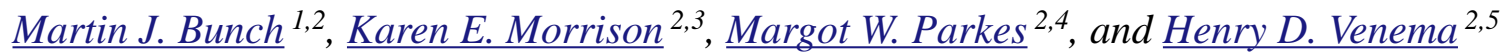

\begin{abstract}
In coupled social-ecological systems, the same driving forces can result in combined social and environmental health inequities, hazards, and impacts. Policies that decrease social inequities and improve social cohesion, however, also have the potential to improve health outcomes and to minimize and offset the drivers of ecosystem change. Actions that address both biophysical and social environments have the potential to create a "double dividend" that improves human health, while also promoting sustainable development. One promising approach to managing the complex, reciprocal interactions among ecosystems, society, and health is the integration of the ecohealth approach (which holds that human health and well-being are both dependent on ecosystems and are important outcomes of ecosystem management) with watershed-based water resources management. Using key management concepts such as resilience, such approaches can help reduce vulnerability to natural hazards, maintain ecological flows of water and the provision of other ecological services, and promote long-term sustainability of coupled human and natural systems. Priorities for understanding and realizing health benefits of watershed management include (i) addressing poverty and reducing inequities, (ii) promoting resilience (for health) in watersheds, and (iii) applying watersheds as a context for intersectoral management tools and policy integration. Examples of work linking health and watershed management demonstrate that not only is appreciation of complex systems important, but an effective approach is participatory and transdisciplinary and gives attention to equity and historical context.
\end{abstract}

Key Words: ecohealth; ecosystem approach; environment and health; environmental determinants of health; health promotion; integrated water resources management; resilience; social determinants of health; watershed governance; watershed management

\section{INTRODUCTION}

Strong synergies exist among ecosystem approaches to health promotion, natural resources management, and poverty reduction. Specific implementation guidance that captures these key concepts is, however, scant. A promising approach to address this gap is to integrate two emergent approaches to environmental management: (1) ecohealth, which holds that human health and well-being are both dependent on ecosystems and are important outcomes of ecosystem management, and (2) watershed-based integrated water resources management (IWRM), which employs watersheds as appropriate units for managing ecosystems (Parkes et al. 2010).

Watersheds are effective units in which to link our discussion of water and health management because of the function of water as the "bloodstream" of both the anthropogenic world and the non-human world (e.g., Falkenmark and Folke 2002). The watershed also clearly frames upstream and downstream concerns related to water quality and quantity, and watersheds are closely related to the provision of, and access to, ecosystem services that are nonnegotiable determinants of human health and wellbeing. Given the clear link among the hydrological

\footnotetext{
${ }^{1}$ Faculty of Environmental Studies, York University, ${ }^{2}$ Network for Ecosystem Sustainability and Health, ${ }^{3}$ Department of Population Medicine, Ontario Veterinary College, University of Guelph, ${ }^{4}$ Health Sciences Program, University of Northern British Columbia, ${ }^{5}$ International Institute for Sustainable Development
} 
cycle (including how it is affected by climate change), land use, and water resources, watersheds defined at a variety of spatial scales can also be considered natural "settings" for human health and well-being.

Over the past century, the dominant scientific approach to environment and health relationships has examined cause-and-effect relationships between "proximal" environmental exposures and their effects on the health of humans. Much progress has been made with this kind of work, but the complex, reciprocal interactions among ecosystems, society, and health demand a more integrated and systemic approach. In coupled social-ecological systems, linked actions that address both biophysical and social environments have the potential to create a "double-dividend" that improves human health by addressing both its socioeconomic and environmental determinants, while also promoting sustainable development (Parkes et al. 2003).

This work draws from research we undertook for the International Institute for Sustainable Development (IISD) focused on the integration of ecohealth and watershed management approaches with the objective of managing watersheds for the improvement of human health and well-being (Parkes et al. 2008). Our investigation led us to focus on social-ecological resilience in watersheds as a key management concept. In this paper, we present a means of conceptualizing environment and health relationships using ideas from complexity science (including "resilience"), we present watersheds as units for management of such relationships, and we discuss the potential of managing for human health and well-being based on understanding socialecological resilience in watersheds.

\section{CONCEPTUALIZING RELATIONSHIPS AMONG HEALTH, ECOSYSTEMS, AND SOCIETY}

\section{The field of ecohealth}

The turn of the 21 st century witnessed a re-emphasis on the environment as context for human health, including proposals for a "socio-ecologic systems perspective" for epidemiology (McMichael 1999) and a convergence of research, policy, and practice seeking to re-link social and ecological understandings of health (Parkes et al. 2003). One result of these investigations is the emerging field of "ecohealth."

Drawing on anthropology, epidemiology, public health science, geography, and systems ecology, ecohealth researchers and practitioners focus on "ecosystem approaches" to health and sustainability (Kay et al. 1999, Forget and Lebel 2001, WaltnerToews 2001, Lebel 2003, Waltner-Toews 2004, 2009). These initiatives have been supported and complemented by groundwork in the field of "ecosystem health" in the 1990s that sought, in particular, to create an interface among the social, natural, and health sciences (Rapport et al. 1998). Ecohealth has also benefited from its links with the field of "conservation medicine" (Aguirre et al. 2002) and what is sometimes described as "One Health"-linking human and animal health with increased attention to ecosystem context (Zinsstag et al. 2005).

A critical insight from the field of ecohealth is that human health and well-being are important outcomes of effective ecosystem management. This presents researchers, practitioners, and policy makers with the challenges of integrating knowledge from multiple disciplines and demands, and has reinvigorated attention to crossdisciplinary, intersectoral, and multi-stakeholder governance strategies that harness the common ground between public health and sustainable development (Brown et al. 2001, Waltner-Toews 2004, Brown 2007b, Soskolne et al. 2007).

An important feature of the emergence of ecosystem approaches to human health is that they have arisen and been prioritized in a variety of contexts beyond the academy in "developed" countries. For example, capacity building and research funding by Canada's International Development Research Centre's (IDRC) "Ecosystem Approaches to Human Health (Ecohealth)" Program Initiative has funded a growing body of ecohealth research and projects in Africa, Asia, Latin America, and the Middle East (Lebel 2003, De Plaen and Kilelu 2004, Boischio et al. 2009), and has more recently progressed into the development of Communities of Practice in EcoHealth (see: http://publicwebsite.idrc.ca/EN/Pr ograms/Agriculture and the Environment/ Ecosystem Approaches to Human Health/Pages/ default.aspx). 


\section{Resilience and complexity}

In accordance with the ecohealth approach (and other ecosystem approaches), we understand ecosystems and social systems to be complex (as opposed to merely complicated). A very useful expression of this comes from resilience theory and is expressed in a large and growing literature with roots in complexity science and adaptive management. Complex adaptive systems are characterized by processes that act as causal morphogenic feedback loops (Kay et al. 1999). That is, in these systems, a bundle of key relationships operate in a way that leads them to self-organize (and maintain organization) within a limited domain of behavior ${ }^{[1]}$. Such systems are resilient: they maintain structure and functioning despite changes to their internal and external environment. However, these systems may also undergo rapid and surprising change, often running through a cycle in which they repeatedly build structure and then collapse as described in Buzz Holling's famous figure-8 schematic (see Gunderson and Holling 2002). At the release and reorganization stage of this cycle, such systems have a major opportunity for adaptation and innovation (and in the case of human systems, learning).

Understanding phenomena from the perspective of resilience and complexity provides insight into the management of complex adaptive systems, including ecosystems and human societies. For example, we understand that because systems are resilient they may resist external pressure for long periods of time, then undergo sudden and surprising change (Regier and Kay 2002, Sendzimir et al. 2004). We also gain an appreciation that uncertainty related to the complex nature of the phenomena we attempt to manage is irreducible. This requires a change of perspective in management. Instead of attempting to design and implement a "system," we instead encourage the evolution of a complex adaptive system through strategic intervention so that the likelihood of systems evolving toward potential desirable attractors is maximized. Approaches such as adaptive comanagement (e.g., Olsson et al. 2004, Armitage et al. 2007) and the adaptive ecosystem approach (Kay et al. 1999, Bunch 2003) have been informed by the kind of understanding enabled by resilience and complexity theory.

Practical application of resilience and complexity theory to issues that involve both ecosystems and human health has been exemplified by the development of AMESH: An Adaptive Methodology for Ecosystem Sustainability and Health (WaltnerToews et al. 2004, Waltner-Toews and Kay 2005). There has also been increasing recognition of the potential of "resilience" as an integrating concept that bridges health and sustainability concerns across scales from individuals to communities and ecosystems - with application to contexts as varied as agro-ecosystem health (Waltner-Toews and Wall 1997), resilience in rural communities responding to drought, hailstorms, and bushfire (Hegney et al. 2007), community responses to environmental toxins (Morrison 2008, Morrison et al. 2008), and disaster preparedness and recovery (Masten and Obradovic 2007).

Also, strategies to "reduce vulnerability" and "build resilience" have emerged in a range of fields and sectors with a preventive and proactive orientation. Examples include community development, disaster preparedness, sustainability, and public health (Woodward et al. 1998, Ryff and Singer 2003, Turner et al. 2003, Arnold 2005, Pearce 2005, International Strategy for Disaster Reduction (ISDR) 2007, 2008).

\section{WATERSHEDS: A PLACE-BASED APPROACH TO MANAGEMENT}

\section{Watersheds as settings for health and well- being}

Traditionally, our understanding and management of human health has been organized spatially around human constructs such as municipalities, counties, health authorities, and provinces or states. These boundaries often overlook and override the structure and function of ecosystems and create a disjuncture between the objects of management and biophysical processes-in this case, a disconnect between human health and nature. One response to this challenge is to recognize and prioritize watersheds as appropriate spatial units around which to organize management for both health and natural resources.

Watersheds, also referred to as catchments or river basins, are areas defined by the heights of land that separate river systems. Watersheds are organized hierarchically. For example, a watershed will contain sub-watersheds, and may itself fall within a larger drainage basin. The movement of water 
through the landscape and the flow of water from the atmosphere to the land and back again drives what Falkenmark (2003) refers to as a hydrological imperative. It drives a series of processes that provide ecological goods and services that are necessary to human health and well-being.

That "health is created and lived by people within the settings of their everyday life; where they learn, work, play and love" was a central tenet of the Ottawa Charter for Health Promotion (WHO 1986), and provided the basis for the settings approach to health promotion (St. Leger 1997). Although healthy settings have an explicit "ecological" and systemic orientation (Green et al. 1996, Poland et al. 2000, Dooris 2005), such approaches often overlook the specific ecosystems within which their healthy cities, schools, workplaces, or hospitals are embedded. Parkes and Horwitz (2009:94) note that "this results in the incongruous situation of initiatives that are place-based and conceptually 'ecological' but blind to the processes, functions and populations of local ecosystems." The disconnect between healthy settings and ecosystems is especially incongruent given the longstanding recognition of ecosystems as a basis for framing and informing health promotion (Cole et al. 1999, Butler 2006).

Parkes and Horwitz (2009) argue that catchmentbased water-resources management provides fertile ground to rethink the settings approach and envision new "settings" for human health and environmental sustainability. Not only does consideration of water orient public health to the systemic relationships underpinning human health and well-being, but it could also help overcome the missed opportunity to focus on the commonalities between health promotion and sustainable development (von Schirnding 2005, Butler 2006, Boischio et al. 2009, Waltner-Toews 2009). Focusing on watersheds as a setting for health and sustainability encourages a view of health-water relationships that goes beyond the traditional focus of water management on drinking water supply, sanitation, and contaminants. Watersheds are also the basis for livelihoods, employment, food and service provision, and culture and identity, and are intimately linked to the "causes of the causes" of health inequities (Marmot 2007).

Drawing on these ideas, we propose that watershed management approaches such as IWRM can provide a useful framework for action that relates to both environmental issues and the social determinants of health. The Global Water Partnership (2000:22) defines IWRM as "a process which promotes the coordinated development and management of water, land and related resources, in order to maximize the resultant economic and social welfare in an equitable manner without compromising the sustainability of vital ecosystems."

One of the challenges of IWRM lies in the pervasiveness of water as a social, cultural, economic, ecological, technical, and political construct. Water resources management is, among other things: a livelihood issue, a land-use issue, an industrial and agricultural development issue, an aesthetic and spiritual issue, a social equity issue, a climate change issue, an environmental issue, a governance issue, an urban issue, and a human health issue. In part because of this, watershed governance requires collective, often multistakeholder, processes that have considerable overlap with those familiar to health promotion (Parkes and Horwitz 2009). We view watershed governance (which encompasses management) as a social process that should involve adaptive management (Allen 1997, Habron 2003), social learning (Keen et al. 2005, Pahl-Wostl 2006) and often collective decision making (Brown 2007a, c). Such social processes have strong potential to fulfill both ecosystem management and public health objectives.

\section{Ecological goods and services provided by watershed ecosystems}

Corvalan et al. (2005:27) note that ecosystem services are:

...the benefits people obtain from ecosystems. These include provisioning services, such as food and water; regulating services, such as regulation of floods, drought, land degradation, and disease; supporting services, such as soil formation and nutrient cycling; and cultural services, such as recreational, spiritual, religious, and other nonmaterial benefits.

Applying the concept of "ecological goods and services" in watershed management, we seek to manage catchment areas "as an asset that delivers a bundle of water and ecological goods and services" (Falkenmark 2000:351). An overview of potential 
ecological goods and services provided by watersheds is elaborated in Table 1.

A demonstration of this concept that links human health and watershed management is provided by Berbés-Blázquez (2010). Berbés-Blázquez collaborated with local actors in the Río Volcán watershed in southern Costa Rica to identify relationships among health/well-being and ecosystem services. She reports that community members linked human health and well-being with provisioning services through food sources and income generation, fresh water, and medicinal plants. Similarly, they identified regulating services as important to environmental health (that maintains provisioning capacities of ecosystems) and for buffering against natural disasters such as flooding. Cultural services were important from the perspective of recreational uses, aesthetic values, and historical sense of place and community. Identification of these relationships now informs an ongoing participatory ecohealth and watershed management program in the Río Volcán watershed.

\section{SOCIAL-ECOLOGICAL RESILIENCE IN WATERSHEDS}

Below, we present several areas where watershed management has particular relevance to human health and well-being. Such a discussion could easily devolve to the conclusion that "everything is connected to everything else" and promote despair about the possibility of managing such situations. However, systems-based approaches such as IWRM and the ecohealth approach are specifically designed for this. Also, the environmental management literature suggests that, in most situations, there will be about five key relationships (the "rule of hand") that if managed effectively can allow for management of the overall system configuration and related social and environmental (and human health) outcomes (Holling 2001, Walker et al. 2006).

\section{Watershed settings for the burden of water- related disease}

Recent WHO reports have paid particular attention to the role of water in the environmental burden of disease (Prüss-Üstün et al. 2004, Prüss-Üstün and Corvalan 2005), estimating that $88 \%$ of all cases of diarrhea globally were attributable to water, sanitation, and hygiene (Prüss-Üstün et al. 2004). The WHO (2004) also identified as "water-related" indicators of severity of global morbidity and mortality such as trachoma, schistosomiasis, and intestinal helminthes. Globally, there have also been major water-related epidemics of toxoplasmosis, Cryptosporidia, giardiasis, hepatitis, E. coli, Campylobacter, and Cyclospora-many of which have been implicitly attributed to poor watershed management and its links with municipal drinking water supplies and sewage treatment (Bowie et al. 1997, Wu et al. 1999).

Water-related diseases are only one component of an array of direct and indirect health impacts related to water resources that can be improved through sustainable watershed management. For example, in many developing countries, providing access to improved drinking-water sources has the potential to considerably reduce the time spent by women and children in collecting water and to trigger a range of educational and economic benefits that improve the social determinants of health. In similar settings, providing access to improved sanitation and good hygiene behaviors would help break the overall cycle of fecal-oral pathogen contamination of waterbodies, yielding benefits to human health, poverty reduction, well-being, and economic development (Prüss-Üstün and Corvalan 2005).

From the perspective of managing for resilience in watersheds, approaching the burden of disease requires development of an understanding of key persistent relationships between the ecosystem context and such disease, so that they can be managed. David Waltner-Toews (2004) undertook such a process with stakeholders in Kathmandu. He summarized part of a process of building a conceptual model of links between gastrointestinal disease and human and physical contexts that led to greening activities for prevention of diarrhea:

... we might ask: how do we decrease GI disease? ... By giving people better access to taps and toilets. What does that require? Water. Where does the water come from? Rain catchment tanks and groundwater. Can we alter rainfall? Not in the short run. Can we improve our ability to catch the rain? Yes, through better tanks and through planting of trees, shrubs and gardens to prevent rainwater from draining directly into the river and creating floods. This greening activity, furthermore, may well 
Table 1. Overview of ecological goods and services provided within watersheds (Parkes et al. (2008) after the matrix presented by Moberg and Folke (1999) for coral reefs).

\begin{tabular}{|c|c|c|c|c|c|c|c|}
\hline \multicolumn{2}{|c|}{ Goods } & \multicolumn{6}{|c|}{ Ecological Services } \\
\hline $\begin{array}{l}\text { Renewable } \\
\text { Resources }\end{array}$ & $\begin{array}{l}\text { Non- } \\
\text { renewable } \\
\text { Resources }\end{array}$ & $\begin{array}{l}\text { Physical } \\
\text { Structure } \\
\text { Services }\end{array}$ & $\begin{array}{l}\text { Biotic } \\
\text { Services } \\
\text { within } \\
\text { Ecosystems }\end{array}$ & $\begin{array}{l}\text { Biotic } \\
\text { Services } \\
\text { between } \\
\text { Ecosystems }\end{array}$ & $\begin{array}{l}\text { Biogeochemical } \\
\text { Services }\end{array}$ & $\begin{array}{l}\text { Informational } \\
\text { Services }\end{array}$ & $\begin{array}{l}\text { Social and } \\
\text { Cultural } \\
\text { Services }\end{array}$ \\
\hline $\begin{array}{l}\text { Agricultural and } \\
\text { forestry } \\
\text { products }\end{array}$ & $\begin{array}{l}\text { Ore } \\
\text { including } \\
\text { aggregate }\end{array}$ & $\begin{array}{l}\text { Shoreline / } \\
\text { riverbank } \\
\text { creation and } \\
\text { erosion }\end{array}$ & $\begin{array}{l}\text { Maintenance } \\
\text { of habitats } \\
\text { Maintenance }\end{array}$ & $\begin{array}{l}\text { Biological } \\
\text { support } \\
\text { through links } \\
\text { to ecozones }\end{array}$ & $\begin{array}{l}\text { Nutrient } \\
\text { cycling } \\
\text { Primary }\end{array}$ & $\begin{array}{l}\text { Monitoring } \\
\text { and pollution } \\
\text { record }\end{array}$ & $\begin{array}{l}\text { Mitigate } \\
\text { drought, } \\
\text { floods, } \\
\text { landslides }\end{array}$ \\
\hline $\begin{array}{l}\text { Municipal and } \\
\text { industrial water } \\
\text { and other } \\
\text { resources }\end{array}$ & $\begin{array}{l}\text { Soil } \\
\text { generation } \\
\text { Oil and gas }\end{array}$ & $\begin{array}{l}\text { Land } \\
\text { drainage } \\
\text { Moderate }\end{array}$ & $\begin{array}{l}\text { of } \\
\text { biodiversity } \\
\text { and a genetic } \\
\text { library }\end{array}$ & $\begin{array}{l}\text { and biomes / } \\
\text { Maintenance } \\
\text { of large-scale } \\
\text { habitats }\end{array}$ & $\begin{array}{l}\text { production } \\
\mathrm{CO}_{2} \text { regulation } \\
\text { / carbon } \\
\text { cycling }\end{array}$ & $\begin{array}{l}\text { Climate } \\
\text { record }\end{array}$ & $\begin{array}{l}\text { Support } \\
\text { recreation and } \\
\text { ecotourism }\end{array}$ \\
\hline $\begin{array}{l}\text { Wildlife } \\
\text { Freshwater } \\
\text { fishery } \\
\text { resources }\end{array}$ & & $\begin{array}{l}\text { weather } \\
\text { extremes }\end{array}$ & $\begin{array}{l}\text { Regulation of } \\
\text { ecosystem } \\
\text { processes and } \\
\text { functions }\end{array}$ & $\begin{array}{l}\text { Export of } \\
\text { organic } \\
\text { production to } \\
\text { other areas' } \\
\text { food webs }\end{array}$ & $\begin{array}{l}\text { Oxygen } \\
\text { production } \\
\text { Waste }\end{array}$ & & $\begin{array}{l}\text { Aesthetic } \\
\text { values and } \\
\text { artistic } \\
\text { inspiration }\end{array}$ \\
\hline $\begin{array}{l}\text { Ecological } \\
\text { flows of water } \\
\text { Groundwater }\end{array}$ & & & $\begin{array}{l}\text { Biological } \\
\text { maintenance } \\
\text { of resilience }\end{array}$ & $\begin{array}{l}\text { Biological } \\
\text { control / } \\
\text { Regulation of } \\
\text { pathogens }\end{array}$ & $\begin{array}{l}\text { assimilation } \\
\text { Detoxification } \\
\text { of wastes }\end{array}$ & & $\begin{array}{l}\text { Sustaining the } \\
\text { livelihood of } \\
\text { communities / } \\
\text { urban areas }\end{array}$ \\
\hline $\begin{array}{l}\text { and rainwater } \\
\text { Hydroelectric } \\
\text { power }\end{array}$ & & & & & $\begin{array}{l}\text { Water } \\
\text { purification }\end{array}$ & & $\begin{array}{l}\text { Support of } \\
\text { cultural, } \\
\text { religious, and } \\
\text { spiritual values }\end{array}$ \\
\hline Fertile soil & & & & & & & \\
\hline $\begin{array}{l}\text { Nearshore } \\
\text { marine } \\
\text { resources }\end{array}$ & & & & & & & \\
\hline $\begin{array}{l}\text { Ornamental } \\
\text { resources }\end{array}$ & & & & & & & \\
\hline
\end{tabular}

\section{help increase future rainfall (Waltner-} Toews 2004:68-69).

This kind of thinking led to the adaptation of an epidemiological/gastrointestinal-focused project into a community-driven riparian restoration and waste-management control project, with multiple potential health promoting spin-offs, including women's leadership, civic pride, increased water access, increased school attendance, and more.
Managing water in watersheds can also address disease beyond those normally considered waterrelated. Hagemeiger et al. (2008), who examined the emergence of avian influenza (H5N1), provide an example. They note that emergence and transmission of the disease depend on interrelated factors such as captivity and domestication of ducks, agricultural practices and land use, and nontraditional husbandry. Public health and veterinary responses to the disease are insufficient, and Hagemeiger et al. (2008) conclude that integrated 
health and environmental management expertise is required. Specifically, to reduce risk of disease to livestock and humans, restoring and preventing further loss of wetlands in Asia is important.

From watershed management and ecohealth perspectives, the interventions Hagemeiger et al. (2008) describe would restore ecosystem services that build resilience for both human and environmental health. The historical context is that agricultural practices and environmental change have led to loss of wetlands in Asia, creating vulnerability in this agroecosystem. Restoration of these wetlands provides habitat (among other things) for wild populations of migratory ducks and geese, reducing contact opportunities among wild and domestic populations of fowl, which is a driver of mutation in the virus. Beyond watershed management for a specific disease, this is also an example of the cross-scale interactions (from wetland/watershed scales to those associated with migratory bird populations, regional and national agricultural systems, and poultry markets) for which insight might be generated through the application of complex adaptive systems approaches such as resilience thinking.

\section{Disaster prevention, watersheds, and public health}

There has been growing awareness of the importance of healthy ecosystems in disaster reduction, including hazard buffer zone protection from wave and storm action, flood protection, water recharge, water purification, and disease mitigation. The conceptual and practical overlaps extend beyond water management and disaster reduction to include human health. An assessment of health impacts of floods (Ahern et al. 2005) highlights the short- and potential long-term human health impacts of water-related disasters. Ahern et al. (2005) found that most flooding deaths were due to drowning, and that injuries occurred when trying to remove oneself, family, or possessions from affected areas, upon return, and during cleaning up. As well as the expected evidence of oral-fecal, vector-borne, and rodent-borne diseases, mental health issues were important-including post-traumatic stress, depression, anxiety, and suicide, with potentially profound impacts to long-term community health and wellbeing. Mold (with associated respiratory impacts) is another major public health issue in water-related disasters.
There is a current lack of integrated and proactive approaches across the fields of water resources management, health promotion, and disaster preparedness. There is also a persistent bias in each field toward "response" rather than prevention, highlighting the paradox that "success is a nonevent" not only for public health (Rose 1985) but also disaster preparedness. Economic arguments to manage watersheds for disaster prevention may be the route to human health in such cases. Johnson et al. (2004), for example, note that the 1993 flood of the Upper Mississippi River caused US\$20 billion in damage. An analysis by Hey and Philippi (1995) indicates that this would not have occurred had not land-use changes undermined the ability of watersheds to provide flood mitigation services. To avoid such disasters, they recommend a comprehensive flood management strategy that involves:

...returning a small portion of the watershed to its native, vegetated state. We can restore -at least in part-a prairie-forest matrix to intercept and hold the precipitation where it falls. We can increase the waterholding capacity of our soils by replenishing their organic content. We can expand the surface-holding capabilities of wetlands, not to the exclusion of agricultural production but in association with that production. Restored riverine and palustrine wetlands could be distributed strategically throughout the watershed (Hey and Philippi 1995:5).

They calculate that the restoration of approximately 13 million acres $(5,261,000 \mathrm{ha})$ (or $17.1 \%$ of the surface area of wetlands and beaver ponds that has been lost since European colonization) would restore the capability of the basin to buffer against a flood such as the 1993 event. The Upper Mississippi River flood disaster and a growing awareness of the importance of watershed services to flood mitigation stimulated the U.S. Fish and Wildlife Services to establish the Big Muddy National Fish and Wildlife Refuge on the Missouri River, a habitat restoration project that also contributes to flood mitigation through the restoration of natural river floodplains and wetlands. Since 1994, the project has seen the acquisition of 11,000 acres $(4,452 \mathrm{ha})$ of a total planned 60,000 acres $(24,281 \mathrm{ha})$, in addition to almost 12,000 properties acquired by the Federal Emergency Management Agency (now part of the 
U.S. Department of Homeland Security) for hazard mitigation (United States Fish and Wildlife Service 2009). In such cases, watershed management has the potential to not only increase both disaster preparedness but enhance socioeconomic determinants of health-not only by reducing direct physical hazards, but also reducing the indirect hazards such as the dramatic loss of livelihood, income, and economic security borne by flood-impacted riparian communities, and the inequitable distribution of impacts ranging from mental health to direct poverty and food security.

\section{Watershed contexts to enhance livelihoods and reduce poverty}

Watershed management can be used as a buffer against poverty through its potential to enhance sustainable livelihoods. The emerging attention to sustainable livelihoods makes a strong case for "inextricable links between poverty reduction and natural resources management" (World Bank 2008) with explicit recognition of the impacts of natural resources management on livelihoods and employment, down to the household level (Ashley 2000, Sendzimir et al. 2004). A livelihoods perspective brings to life the important socioeconomic implications of the ecosystem goods and services of Table 1, especially in agricultural and resource-based economies dependent on sustainable provision of water. Management practices that can have significant impacts on the quality of local watershed ecosystems include fencing of common land to allow for regeneration, construction of check dams and contour trenches, protection of wetlands and riparian buffer zones along waterways, no-till farming, and the promotion of soil and water conservation.

In Madagascar, for example, there is recognition by governmental and non-governmental actors and local stakeholders that protection of biodiversity is linked to livelihoods and human health, e.g., increased poverty can place increased pressure on biodiversity-rich environments, poor health in people can reduce agricultural productivity and, conversely, a healthy, biodiversity-rich ecosystem can contribute positively to human health. This has led to the promotion among some stakeholders of smaller and healthier families in order to achieve the dual goals of biodiversity conservation and rural development (Gaffikin et al. 2007). Gaffikin (2008), for example, reports that coordinated initiatives involving two different program offices (Health, Population and Nutrition and Environment/Rural Development) that worked to achieve "sustainable and inclusive development" under the USAID/ Madagascar 2003-2008 Integrated Strategic Plan,

...demonstrate that achieving biodiversity conservation depends upon rural communities having: 1) access to adequate quantities (and quality) of water and 2) balancing population size increases with NR [natural resources] availability, among other factors. It also demonstrates the belief that for FP [family planning] and safe water to contribute to improved health and economic growth, interventions and services must be extended to the rural poor, a number of whom live close to and depend upon NR from biodiversity priority areas (Gaffikin 2008:85).

Using natural units (forest ecosystems and watersheds) for example, Conservation International's "Healthy Families, Healthy Forests" program in Madagascar has worked with NGOs and communities to train local field agents across a biological corridor to champion a range of public health and environmental issues (Edmond 2008). Beginning with rural health and family planning approaches (leading to dramatic increases in adoption of contraception and vaccination of young children), their work spans into capacity building for sustainable agriculture and conservation efforts. Edmond (2008) reports that between 2005 and 2008 this included working with 11 women's nutritional teams to implement green gardens, replanting trees to restore ecosystems, promoting soil conservation and agroforestry to improve water resources, and construction of 1,950 latrines and 1,860 waste pits in more than 30 communities so as to reduce drinking water contamination and protect the health of local watersheds. All of this work was undertaken in a participatory mode with an eye to the ultimate bottom line of human health and well-being.

The Madagascar example also demonstrates that beyond physical intervention, participatory watershed management approaches (also a characteristic of the ecohealth approach) are important. These seek to empower local communities through, e.g., the creation of watershed councils that represent community stakeholders; programming that works with them to respond to their interests; the provision of leadership training and the creation of structural 
and institutional conditions that can lead to early successes (Hinchcliffe et al. 1999, Turton 2000, Liu et al. 2008). This support tends to involve a range of local, regional, and/or national stakeholders, including government agencies, NGOs, and community groups.

Participatory watershed management processes, however, face the challenge of engaging groups that are often systematically excluded from political and social processes within the watershed (Swallow et al. 2006). Thus, good practice in watershed management processes, like health promotion, needs to explicitly address issues of equity, social justice, and differentials in power (Schulz and Northbridge 2004).

\section{PRIORITY AREAS FOR UNDERSTANDING THE HEALTH BENEFITS OF WATERSHED MANAGEMENT}

Based on our discussion above, we highlight three priority areas for understanding the human health benefits of watershed management: (i) in relation to overcoming poverty and inequalities, (ii) promoting resilience, and (iii) as a context to apply existing tools of environmental health and health promotion. Each of the priority areas are based on a view of watershed-based management as a "doubledividend" strategy_improving human health by addressing both its environmental and social determinants.

\section{(i) Addressing poverty and reducing iInequities}

The most well-established evidence in the social determinants of health literature focuses on inequities as a social hazard that increases morbidity and mortality (Wilkinson and Marmot 2003, Marmot and Wilkinson 2006, Stansfeld 2006). Our proposal is simply that watershed management has the potential to decrease poverty and related drivers of health inequities, and provide an ecosystembased context within which to improve the social determinants of health, or what could even be termed the water-related determinants of health.

Just as studies of human health tend to focus on disease and illness (or a "loss" of health), interrelationships among water resources management, poverty, and the social determinants of health are most dramatically presented through a focus on the deficits associated with a change or "loss" of access to, or availability of water. The links among water resources, poverty, and inequities are especially notable in the contexts of dams and drought, both exacerbated by climate change.

For example, the World Commission on Dams (2000:118) states that "the issue of equity - in terms of pre-existing nutritional and health conditions of the population and the capacity to resist new health problems - is at the root of the adverse health impacts of dams." This also draws attention to inequitable impacts in relation to displacement of people, implications for indigenous peoples, downstream livelihoods, gender, cultural heritage, human health, and equity.

Similarly, in their review of the health consequences of drought in the Canadian Prairies, Smoyer-Tomic and colleagues (2004) make a useful elaboration of the macro and micro factors that cause drought and identify direct and indirect effects on human health ranging from waterborne disease to respiratory effects from fire and dust. Smoyer-Tomic et al. (2004) also highlight the important, but largely overlooked, impacts of drought on mental health in rural and agricultural communities.

The examples of dams and drought exemplify the range of "downstream" implications for the determinants of health when access to or availability of water is compromised. Yet an alternative view is possible by shifting attention from preventing deficits to promoting assets. Prioritizing sustainable watershed management as a strategic asset to improve the determinants of human health, strengthens the case for maintenance (or restoration) of ecosystem integrity, as well as fostering sustainable livelihoods, equity, and social engagement. ${ }^{[2]}$ In this light, integrating ecohealth and watershed management can be seen as a strategy to promote both human health and ecosystem resilience in coupled human and natural systems.

\section{(ii) Promoting resilience (for health) in watersheds}

Although the convergence between promoting human health and ecosystem resilience has been suggested in other literature (for example, WaltnerToews and Wall 1997, Rapport et al. 1998, Hegney et al. 2007), the idea has often lacked a "place" or setting for practical application and implementation. 
We identify watersheds as an ecosystem-based and socially relevant context within which to consider the conceptual and operational links between resilience and human health.

The idea of promoting resilience to improve human health and well-being implies that in the coupling of human and natural systems there are relationships that are important to maintaining current system configurations and domains of behavior. Ecosystem approaches such as ecohealth and IWRM, in their application, need to discover these relationships and manage them, e.g., to undermine those relationships that lead to undesirable human health outcomes and to build or promote those that will be selfmaintaining for desirable outcomes. Each situation will be essentially unique and will require a process of exploration and discovery. However, there will also be basic principles and certain lessons that can be shared across situations.

For example, in proposing that "enduring capacity to respond positively to change and challenges" (a characteristic of resilience) can become a common goal for promoting human health and ecosystem resilience in watersheds, Parkes and Horwitz (2009:100) echo indigenous and place-based understandings of the relationship among health, ecosystems, and communities that have developed over millennia. Inclusion of such knowledge through participation of relevant stakeholders also builds social capital and shared ownership of the process. This can lead to enduring capacity and relationships that underpin resilience in coupled social-ecological systems.

There are many other themes that may be relevant to watershed management for human health and well-being in different contexts-some less and some more commonly applicable. For example, the themes of this paper suggest that multi-stakeholder watershed management provides particularly relevant governance and ecosystem-based contexts in which to apply this kind of thinking, not least to highlight opportunities for convergence and synergies among public health, sustainability governance, and environmental management (Brown 2007b).

\section{(iii) Watersheds as a context for intersectoral management tools and policy integration}

Another priority is the opportunity of integrated watershed management as a context to enable intersectoral policies and apply management tools that can have multiple benefits: for public health, ecosystem sustainability, development, and governance. As an ecosystem context for intersectoral policy integration, watersheds could be the setting to implement a range of innovative and integrative management approaches:

- the converging fields of impact assessment, including environmental impact assessment (EIA) , environmental health impact assessment (EHIA), and health impact assessment (HIA) (Banken 1999, Hegney et al. 2007, Wernham 2007) including explicit consideration of watersheds as the context for land-use planning decisions and their human health implications (Dannenberg et al. 2003, Malizia 2006, Bhatia 2007);

- integrated approaches to security, including water, environmental, food, and human security (Falkenmark and Folke 2002, O'Brien 2006), especially in the context of climate change (Catford 2008, Jones et al. 2008); and

- promoting human health and reducing inequities through attention to environmental (in) justice and inequities (Lee 2002, Gee and Grimpayne-Sturgesalt 2004, Howze et al. 2004, Parizeau 2006, Cifuentes and Frumkin 2007).

\section{CONCLUSIONS}

We conclude by identifying some challenges, gaps, and opportunities for integrating the ecohealth approach with watershed management approaches such as IWRM to promote health and well-being (Table 2). Despite the value that we see in explicitly addressing concerns about human health and wellbeing on a watershed basis, it is apparent that a myriad of challenges exist. These include the challenges of jurisdiction, of integrating academic disciplines, professional fields, and multiple worldviews, of spatial-temporal scale and the 
Table 2. Key challenges and opportunities associated with the integration of watersheds and ecohealth (Parkes et al. 2008).

\begin{tabular}{|c|c|c|c|}
\hline & Research & Policy & Outreach \\
\hline $\begin{array}{l}\text { Spatial-Temporal } \\
\text { Scale }\end{array}$ & $\begin{array}{l}\text { Watersheds offer a meso- } \\
\text { scale unit of analysis that } \\
\text { reflects ecosystem } \\
\text { processes }\end{array}$ & $\begin{array}{l}\text { Watersheds as a new meso-scale } \\
\text { setting for action to improve } \\
\text { social and environmental health } \\
\text { determinants }\end{array}$ & $\begin{array}{l}\text { Watersheds as a scale that } \\
\text { communities can relate to and that } \\
\text { enable a re-integration of social- } \\
\text { ecological issues }\end{array}$ \\
\hline $\begin{array}{l}\text { The Paradox of } \\
\text { Promoting Health }\end{array}$ & $\begin{array}{l}\text { "Attribution" of specific } \\
\text { health improvements to } \\
\text { watershed changes is } \\
\text { challenging }\end{array}$ & $\begin{array}{l}\text { Success in health promotion can } \\
\text { be considered a non-event and is } \\
\text { harder to measure than disease } \\
\text { prevention }\end{array}$ & $\begin{array}{l}\text { Public may also struggle to identify / } \\
\text { recognize health gains as a result of } \\
\text { watershed actions }\end{array}$ \\
\hline $\begin{array}{l}\text { Ecological Goods } \\
\text { and Services } \\
\text { (EGAS) on a } \\
\text { Watershed Basis }\end{array}$ & $\begin{array}{l}\text { Potential to link the } \\
\text { research agendas relating } \\
\text { to EGAS, livelihoods, and } \\
\text { social determinants of } \\
\text { health }\end{array}$ & $\begin{array}{l}\text { Valuing ecological goods and } \\
\text { services within a watershed } \\
\text { context may help drive more } \\
\text { integrated cross-sectoral } \\
\text { approaches }\end{array}$ & $\begin{array}{l}\text { EGAS may be assisted with } \\
\text { communication about health impacts } \\
\text { of watersheds }\end{array}$ \\
\hline $\begin{array}{l}\text { Poverty and } \\
\text { Watersheds }\end{array}$ & $\begin{array}{l}\text { Linking research agendas } \\
\text { across health, ecosystems } \\
\text { and society (especially in } \\
\text { relation to reducing } \\
\text { inequities) }\end{array}$ & $\begin{array}{l}\text { Potential to link services and } \\
\text { policies across health, } \\
\text { sustainability, and disaster } \\
\text { reduction objectives. }\end{array}$ & $\begin{array}{l}\text { Initiatives to sustain ecosystems, } \\
\text { livelihoods, and reduce quality could } \\
\text { have profound health benefits }\end{array}$ \\
\hline $\begin{array}{l}\text { Governance } \\
\text { Challenges }\end{array}$ & $\begin{array}{l}\text { Evaluating the role of } \\
\text { watersheds as a place- } \\
\text { based context in which to } \\
\text { govern for both health and } \\
\text { sustainability }\end{array}$ & $\begin{array}{l}\text { Call for Health in all policies, } \\
\text { pose new opportunities to link } \\
\text { IWRM and public health }\end{array}$ & $\begin{array}{l}\text { Communities could benefit from } \\
\text { increased integration of services to } \\
\text { achieve multiple objectives }\end{array}$ \\
\hline $\begin{array}{l}\text { "New Generation" } \\
\text { Policy Instruments }\end{array}$ & $\begin{array}{l}\text { A focus on watersheds as a } \\
\text { setting to link and } \\
\text { integrate tools, including } \\
\text { impact assessments, } \\
\text { indicators, risk, } \\
\text { surveillance }\end{array}$ & $\begin{array}{l}\text { Policy leadership will be } \\
\text { necessary to encourage proactive } \\
\text { instruments and integration } \\
\text { between approaches at the } \\
\text { watershed scale. }\end{array}$ & $\begin{array}{l}\text { Demand for accessible and } \\
\text { community-relevant policy } \\
\text { instruments may drive policy } \\
\text { innovation and integration at the } \\
\text { watershed scale. }\end{array}$ \\
\hline $\begin{array}{l}\text { Building Capacity } \\
\text { For a Paradigm } \\
\text { Shift }\end{array}$ & $\begin{array}{l}\text { Conceptualizing and } \\
\text { managing complex } \\
\text { adaptive social-ecological } \\
\text { systems for human health. }\end{array}$ & $\begin{array}{l}\text { Policy may need to drive and } \\
\text { demand new approaches to } \\
\text { training and knowledge } \\
\text { translation. Mechanisms for } \\
\text { crossing jurisdictional barriers } \\
\text { need to be implemented. }\end{array}$ & $\begin{array}{l}\text { Watershed-based ecohealth case } \\
\text { studies can support extension of the } \\
\text { approach to governmental actors and } \\
\text { other stakeholders. Communities of } \\
\text { practice and funded training in } \\
\text { ecohealth are required. }\end{array}$ \\
\hline
\end{tabular}

relationship between systems defined at different scales, and of the complexity of the issues pertaining to each aspect of these social-ecological systems (including climate and atmospheric processes, land uses, ecological processes, social networks, livelihoods, and lifestyles). Traditional (mechanistic) management and governance structures and (reductionist) science fall short with respect to such issues: attempts to apply command-and-control approaches to manage decentralized processes, undertake rational planning in situations of high levels of uncertainty, and requirements to identify (up front) and account for impacts of projects in the face of multiple interacting relationships and evolving situations are at best problematic (Bavington 2002, Berkes 2003, Chapman 2004, Innes and Booher 2010). 
Approaches to governance and management that are more appropriate to such complex situations must be explored. For example, Lebel et al. (2006) have demonstrated that governance for resilience in regional social-ecological systems is effective if: it is participatory (building trust, shared understanding, and promoting engagement by stakeholders); involves polycentric and multilayered institutions (that allow adaptive responses at appropriate scales); and in which accountable authorities focus attention on equity and adaptive capacity of vulnerable groups and society. This kind of approach matches well with the three pillars of the ecohealth approach as expressed by IDRC: participation, transdisciplinarity, and equity (Lebel 2003). Another useful approach to guide governance of watersheds for human health and well-being is one oriented to social learning. Social learning focuses on the development of shared meanings, new institutions, and capacity at the level of the social entity as a result of participation and collaboration, and learning generated by feedback between project outcomes and the problem context (Pahl-Wostl et al. 2007, Steyaert and Jiggins 2007). Supplemental to work such as this, Parkes et al. (2010) present another useful model - a watershed governance "prism" that portrays six axes among ecosystems, watersheds, social systems, and health/ well-being, and four perspectives on watershed governance. This can ground discussion and collaboration around the multiple and converging benefits of watershed and ecohealth approaches.

Such work, that addresses governance in complex social-ecological systems, demonstrates potential avenues to management of watersheds for human health and well-being. Moreover, the examples we present in this paper draw out some specific aspects of how such initiatives can be implemented: the participatory, collaborative, and empowering nature of the work with stakeholders in Costa Rica and Madagascar, thinking across disciplines and scales such as is evident when linking wetland conservation and avian influenza in Asia and gastrointestinal disease and watersheds in Katmandu, attention to historical context in ecosystem functions in the Upper Mississippi River and, in all the examples, attention to understanding the relationships among watershed processes, ecological goods and services, and human health and well-being. Despite the obstacles, we view that the opportunity and potential outweigh the challenges, with integrated watershed management and ecohealth providing a vehicle to address converging human health, social, and environmental objectives.

[1] Informally, "domain of behavior" describes the extent and range of important system variables that characterize a dynamically stable system configuration known in complexity science as an attractor. Outside of that range a system may "flip" - variously described in complexity science as a bifurcation, phase transition, or catastrophe threshold-and reorganize around an alternative attractor (see Regier and Kay 2002 for examples).

[2] "Ecosystem integrity" describes an emergent property of ecosystems arising from interrelationships and processes that provide the capability to maintain an ecosystem's current operating point and/or to evolve to other (near) optimal states (system configurations) (Kay 1991, Müller et al. 2000). In using the concept, however, the emphasis is usually on the presence and functioning of ecosystem components that lead to "integrity." For example, the Panel on the Ecological Integrity of Canada's National Parks (Parks Canada Agency 2000) states that "ecosystems have integrity when they have their native components (plants, animals and other organisms) and processes (such as growth and reproduction) intact."

Responses to this article can be read online at: http://www.ecologyandsociety.org/voll6/iss 1/art6/responses/

\section{Acknowledgments:}

The authors wish to acknowledge the contributions of anonymous reviewers to this paper and thank Lynne Gaffikin andMarta Berbés-Blázquezfor their contribution and correspondence with respect to their case studies upon which we report. This project was undertaken with funding support from the International Institute for Sustainable Development (IISD). Such support does not indicate endorsement by IISD of the contents of this material. 


\section{LITERATURE CITED}

Aguirre, A. A., R. S. Ostfeld, G. M. Tabor, C. House, and M. C. Pearl. 2002. Conservation medicine: ecological health in practice. Oxford University Press, New York, New York, USA.

Ahern, M., R. Kovats, P. Wilkinson, R. Few, and F. Matthies. 2005. Global health impacts of floods: epidemiologic evidence. Epidemiologic Reviews 27:36-46.

Allen, W. J. 1997. Towards improving the role of evaluation within natural resource management r\&d programs: the case for learning by doing. Canadian Journal of Development Studies XVIII:629-643.

Armitage, D., F. Berkes, and N. Doubleday. 2007. Adaptive comanagement: collaboration, learning, and multi-level governance. University of British Columbia Press, Vancouver, British Columbia, Canada.

Arnold, J. 2005. Risk and risk assessment in health emergency management. Prehospital Disaster Medicine 20(3):143-54.

Ashley, C. 2000. Applying livelihood approaches to natural resource management initiatives: experiences in Namibia and Kenya. Overseas Development Institute, London, UK.

Banken, R. 1999. From concept to practice: including the social determinants of health in environmental assessments Canadian Journal of Public Health/Revue Canadienne de Santé Publique 90:S27-30.

Bavington, D. 2002. Managerial ecology and its discontents: exploring the complexity of control, careful use and coping in resource and environmental management. Environments 30:321.

Berbés-Blázquez, M. 2010. A participatory assessment of ecosystem services and human wellbeing in rural Costa Rica using photo-voice Environmental Management:(Submitted).

Berkes, F. 2003. Alternatives to conventional management: lessons from small-scale fisheries Environments 31:5-19.
Bhatia, R. 2007. Protecting health using an environmental impact assessment: a case study of San Francisco land use decision making. American Journal of Public Health 97:406-413.

Boischio, A., A. Sánchez, Z. Orosz, and D. Charron. 2009. Health and sustainable development: challenges and opportunities of ecosystem approaches in the prevention and control of dengue and chagas disease. Cadernos de Saude Publica Sup 1:S149-S154.

Bowie, W. R., A. S. King, D. H. Werker, J. L. IsaacRenton, A. Bell, S. B. Eng, and S. A. Marion. 1997. Outbreak of toxoplasmosis associated with municipal drinking water. The Lancet 350: 173177.

Brown, V. A. 2007a. Collective decision-making bridging public health, sustainabilty governance and environmental management. Pages 139-153 in C. Soskolne, L. Westra, L. J. Kotzé, B. Mackey, W. E. Rees, and R. Westra, editors. Sustaining life on earth: environmental and human health through global governance. Lexington Books, Plymouth, UK.

Brown, V. A. 2007b. Collective thinking for a connected world: combining knowledges towards whole-of-community change. Pages 30-39 in Organizing Committee for the Asia-Pacific Ecohealth Conference. Ecology and health: people and places in a changing world. Asia-Pacific Ecohealth Conference, 30 November-3 December 2007, Melbourne, Australia.

Brown, V. A. 2007c. Leonardo's vision: a guide to collective thinking and action. Sense Publishers, Rotterdam, The Netherlands.

Brown, V. A., R. Nicholson, P. Stephenson, K.-J. Bennet, and J. Smith. 2001. Grass-roots and common ground. Guidelines for community-based environmental health action: a discussion paper. Regional Integrated Monitoring Centre, University of Western Sydney, Western Sydney, Australia.

Bunch, M. J. 2003. Soft systems methodology and the ecosystem approach: a system study of the Cooum River and environs in Chennai, India. Environmental Management 31:182-197. 
Butler, C. 2006. Ecosystems and health promotion. PLoS Medicine 3:1692-1695.

Catford, J. 2008. Food security, climate change and heath promotion: opening up the streams not just helping out down stream. Health Promotion International 23:105-108.

Chapman, J. 2004. System failure: why governments must learn to think differently. Demos, London, UK.

Cifuentes, E., and H. Frumkin. 2007. Environmental injustice: case studies from the south. Environmental Research Letters 2:045034.

Cole, D. C., J. Eyles, B. L. Gibson, and N. Ross. 1999. Links between humans and ecosystems: the implications of framing for health promotion strategies. Health Promotion International 14:6572.

Corvalan, C., S. Hales, and A. McMichael. 2005. Ecosystems and human well-being: health synthesis. World Health Organization, Geneva, Switzerland.

Dannenberg, A., R. Jackson, H. Frumkin, and R. Schieber. 2003. The impact of community design and land-use choices on public health: a scientific research agenda. American Journal of Public Health 93:1500-1508.

De Plaen, R., and C. Kilelu. 2004. From multiple voices to a common language: ecosystem approaches to human health as an emerging paradigm. EcoHealth 1:SU8-SU15.

Dooris, M. 2005. Healthy settings: challenges to generating evidence of effectiveness. Health Promotion International 21:55-65.

Edmond, J. 2008. Conservation international's population, health and environment program. Basins and Coasts 2:11-17.

Falkenmark, M. 2000. How to bring ecological services into integrated water resources management. AMBIO: A Journal of the Human Environment 29:351-352.

Falkenmark, M. 2003. Water management and ecosystems: living with change, background paper no. 9. Global Water Partnership Technical Advisory Committee, Stockholm, Sweden.
Falkenmark, M., and C. Folke. 2002. The ethics of socio-ecohydrological catchment management: towards hydrosolodarity. Hydrology and Earth System Sciences 6:1-9.

Forget, G., and J. Lebel. 2001. An ecosystem approach to human health. International Journal of Occupational and Environmental Health 7:S1-S36.

Gaffikin, L. 2008. Scaling up population and environment approaches in Madagascar: a case study. World Wildlife Fund and Evaluation and Research Technologies for Health (EARTH) Inc., Washington, D.C., USA.

Gaffikin, L., J. Ashley, and P. D. Blumenthal. 2007. Poverty reduction and millennium development goals: recognizing population, health, and environment linkages in rural Madagascar. Medscape General Medicine (MedGenMed) 9 (4):17. [online] URL: http://www.ncbi.nlm.nih.gov/ pmc/articles/PMC2234285/.

Gee, G. C., and D. C. Grimpayne-Sturgesalt. 2004. Environmental health disparities: a framework integrating psychosocial and environmental concepts. Environmental Health Perspectives 112:1645-1653.

Global Water Partnership. 2000. Integrated water resources management. 4, Global Water Partnership, Stockholm, Sweden.

Green, L. W., L. Richard, and L. Potvin. 1996. Ecological foundations of health promotion. American Journal of Health Promotion 10:270281.

Gunderson, L., and C. S. Holling, editors. 2002. Panarchy: understanding transformations in human and natural systems. Island Press, Washington, D.C., USA.

Habron, G. 2003. Role of adaptive management for watershed councils. Environmental Management 31:29-41.

Hagemeijer, W., V. Martin, W. Karesh, and S. Newman. 2008. Managing wetlands for people and nature to minimize the risks of disease-an example of avian influenza. Pages 91-99 in M. Ounsted and J. Madgwick, editors. Healthy wetlands, healthy people: report of the Shaoxing City symposium. Wetlands International, Wageningen, The Netherlands. 
Hegney, D., E. Buikstra, P. Baker, C. Rogers-Clark, S. Pearce, H. Ross, C. King, and A. Watson-Luke. 2007. Individual resilience in rural people: a Queensland study, Australia. Rural and Remote Health 7:620.

Hey, D. L., and N. S. Philippi. 1995. Flood reduction through wetland restoration: the Upper Mississippi River basin as a case history. Restoration Ecology 3:4-17.

Hinchcliffe, F., J. Thompson, J. N. Pretty, I. Guijt, and P. Shaw, editors. 1999. Fertile ground: the impacts of participatory watershed initiatives. ITDG Publishing, London, UK.

Holling, C. S. 2001. Understanding the complexity of economic, ecological, and social systems. Ecosystems 4:390-405.

Howze, E. H., G. T. Baldwin, and M. C. Kegler. 2004. Environmental health promotion: bridging traditional environmental health and health promotion. Health Education and Behaviour 31:429-440.

Innes, J. E., and D. E. Booher. 2010. Planning with complexity: an introduction to collaborative rationality for public policy. Routledge, New York, New York, USA.

International Strategy for Disaster Reduction (ISDR). 2007. Words into action: a guide for implementing the Hyogo framework. in Hyogo framework for action 2005-2015: Building the resilience of nations and communities to disasters. United Nations, ISDR, Geneva, Switzerland.

ISDR. 2008. Towards national resilience: good practices of national platforms for disaster risk reduction. - 2008. United Nations Secretariat of the International Strategy for Disaster Reduction (UN/ ISDR), Geneva, Switzerland.

Johnson, G. P., R. R. Holmes, Jr., and L. A. Waite. 2004. The great flood of 1993 on the Upper Mississippi River-10 years later. U.S. Geological Survey, Urbana, Illinois, USA.

Jones, P., A. Larson, and I. Couper. 2008. The future, our rural populations and climate change- a special issue of rural and remote health. Rural and Remote Health 8 1039. (online) URL: http://www.r rh.org.au/articles/subviewnew.asp?ArticleID=1039

Kay, J. J. 1991. A nonequilibrium thermodynamic framework for discussing ecosystem integrity. Environmental Management 15:483-495.

Kay, J. J., M. Boyle, H. A. Regier, and G. Francis. 1999. An ecosystem approach for sustainability: addressing the challenge of complexity. Futures 31:721-742.

Keen, M., V. A. Brown, and R. Dyball. 2005. Social learning in environmental management-building a sustainable future. Earthscan Publications, London, UK.

Lebel, J. 2003. Health: an ecosystem approach. International Development Research Centre, Ottawa, Ontario, Canada.

Lebel, L., J. M. Anderies, B. Campbell, C. Folke, S. Hatfield-Dodds, T. P. Hughes, and J. Wilson. 2006. Governance and the capacity to manage resilience in regional social-ecological systems. Ecology and Society 11: 19. [online] URL: http://w ww.ecologyandsociety.org/vol11/iss11/art19/.

Lee, C. 2002 Environmental justice: building a unified vision of health and the environment. Environmental Health Perspectives 110:141-144.

Liu, B. M., Y. Abebe, O. V. McHugh, A. S. Collick, B. Gebrekidan, and T. S. Steenhuis. 2008. Overcoming limited information through participatory watershed management: case study in Amhara, Ethiopia. Physics and Chemistry of the Earth 33:1321.

Malizia, E. 2006. Planning and public health: research options for an emerging field. Journal of Planning Education and Research 25:428-432.

Marmot, M. 2007. Achieving health equity: from root causes to fair outcomes. The Lancet 370:11531163.

Marmot, M., and R. Wilkinson, editors. 2006. Social determinants of health). Second edition. Oxford University Press, Oxford, UK. 
Masten, A. S., and J. Obradovic. 2007. Disaster preparation and recovery: lessons from research on resilience in human development. Ecology and Society 13(1): 9. [online] URL: http://www.ecology andsociety.org/vol13/iss1/art9/.

McMichael, A. J. 1999. Prisoners of the proximate: loosening the constraints on epidemiology in an age of change. American Journal of Epidemiology 149:887-897.

Moberg, F., and C. Folke. 1999. Ecological goods and services of coral reef ecosystems Ecological Economics 29:215-233

Morrison, K. 2008. Situated learning, socialecological resilience and human health: Ciguatera fish poisoning in Cuba. VDM Academic Publishers, Saarbrucken, Germany.

Morrison, K., P. Aguiar Prieto, A. Castro Domínguez, D. Waltner-Toews, and J. FitzGibbon. 2008. Ciguatera fish poisoning in La Habana, Cuba: a study of local social-ecological resilience. EcoHealth 5:346-359.

Müller, F., R. Hoffmann-Kroll, and H. Wiggering. 2000. Indicating ecosystem integrity - theoretical concepts and environmental requirements. Ecological Modelling 130:13-23.

O'Brien, K. 2006. Are we missing the point? Global environmental change as an issue of human security. Global Environmental Change 16:1-3.

Olsson, P., C. Folke, and F. Berkes. 2004. Adaptive comanagement for building resilience in socialecological systems. Environmental Management 34:75-90.

Pahl-Wostl, C. 2006. The importance of social learning in restoring the multifunctionality of rivers and floodplains. Ecology and Society 11(1): 10. (online) URL: http://www.ecologyandsociety.org/voll1/ iss1/art10/.

Pahl-Wostl, C., M. Crops, A. Dewulf, E. Mostert, D. Tabara, and T. Taillieu. 2007. Social learning and water resources management. Ecology and Society 12(2): 5. [online] URL: http://www.ecology andsociety.org/vol12/iss2/art5/.
Parizeau, K. 2006. Theorizing environmental justice: environment as a social determinant of health. Pages 101-129 in J. C. Cohen and L. Forman, editors. Comparative program on health and society. Lupina Foundation working papers series, Comparative Program on Health and Society, University of Toronto, Toronto, Ontario, Canada.

Parkes, M. W., and P. Horwitz. 2009. Water, ecology and health: ecosystems as settings for promoting health and sustainability. Health Promotion International 24:94-102.

Parkes, M. W., K. E. Morrison, M. J. Bunch, and H. D. Venema. 2008. Ecohealth and watersheds: ecosystem approaches to re-integrate water resources management with health and well-being. NESH Publication Series No. 2 International Institute for Sustainable Development, Winnipeg, Manitoba, Canada.

Parkes, M. W., K. E. Morrison, M. J. Bunch, H. D. Venema, L. K. Hollstrom, R. C. Neudoerffer, H. D. Venema, and D. Waltner-Toews. 2010. Towards integrated governance for water, health and socialecological systems: the watershed governance prism. Global Environmental Change, DOI: 10.1016/j.gloenvcha.2010.1006.1001.

Parkes, M. W., R. Panelli, and P. Weinstein. 2003. Converging paradigms for environmental health theory and practice. Environmental Health Perspectives 111:669-675.

Parks Canada Agency. 2000. "Unimpaired for future generations?" Protecting ecological integrity with Canada's national parks. Vol. I A call to action. Vol. II Setting a new direction for Canada's national parks. Minister of Public Works and Government Services, Government of Canada, Ottawa, Ontario, Canada.

Pearce, L. 2005. The value of public participation during a hazard, impact, risk and vulnerability (HIRV) analysis. Mitigation and Adaptation Strategies for Global Change 10:411-441.

Poland, B., L. Green, and I. Rootman. 2000. Settings for health promotion: Linking theory and practice. Sage, London, UK.

Prüss-Üstün, A., and C. Corvalan. 2005. Preventing disease through healthy environments: towards an 
estimate of the environmental burden of disease. World Health Organization, Geneva, Switzerland.

Prüss-Üstün, A., D. Kay, L. Fewtrell, and J. Bartram. 2004. Unsafe water, sanitation and hygiene. In M. L. A. Ezzati, A. Rodgers, and C. L. Murray, editors. Comparative quantification of health risks. World Health Organization, Geneva, Switzerland.

Rapport, D. J., R. Constanza, and A. J. McMichael. 1998. Assessing ecosystem health: challenges at the interface of social, natural and health sciences. TREE (Trends in Ecology and Evolution) 13:397-402 .

Regier, H. A., and J. J. Kay. 2002. Phase shifts and flip-flops in complex systems. Pages 422-429 in T. Munn, editor. Encyclopedia of global environmental change, volume 5: Social dimensions of global environmental change. Wiley, Chichester, UK.

Rose, G. 1985. Sick individuals and sick populations. International Journal of Epidemiology 14:32-38.

Ryff, C. D., and B. Singer. 2003. Thriving in the face of challenge: the integrative science of human resilience. Pages 181-205 in F. Kessel, P. Rosenfield, and N. Anderson, editors. Expanding the boundaries of health and social science: case studies in interdisciplinary innovation. Oxford University Press, New York, New York, USA.

Schulz, A., and M. Northbridge. 2004. Social determinants of health: implications for environmental health promotion. Health Education and Behaviour 31:455-471.

Sendzimir, J., P. Balogh, A. Vari, and T. Lantos. 2004. The Tisza river basin: Slow change leads to sudden crisis. in $\mathrm{S}$. Light, editor. The role of biodiversity conservation in the transition to rural sustainability. IOS Press, Amsterdam, The Netherlands.

Smoyer-Tomic, K. E., J. D. A. Klaver, C. L. Soskolne, and D. W. Spady. 2004. Health consequences of drought on the Canadian prairies. EcoHealth 1:SU144-SU154.

Soskolne, C., L. Westra, L. J. Kotzé, B. Mackey, W. E. Rees, and R. Westra, editors. 2007. Sustaining life on earth: environmental and human health through global governance. Lexington Books, Plymouth, UK.

St. Leger, L. 1997. Health promoting settings: from Ottawa to Jakarta. Health Promotion International 12:99-101.

Stansfeld, S. A. 2006. Social support and social cohesion. Pages 148-171 in M. Marmot and R. Wilkinson, editors. Social determinants of health. Second edition. Oxford University Press, Oxford, UK.

Steyaert, P., and J. Jiggins. 2007. Governance of complex environmental situations through social learning: a synthesis of slim's lessons for research, policy and practice. Environmental Science and Policy 10:575-586.

Swallow, B., N. Johnson, R. Meinzen-Dick, and A. Knox. 2006. The challenges of inclusive cross-scale collective action in watersheds. Water International 31:361-375.

Turner, B. L., R. E. Kasperson, P. A. Matson, J. J. McCarthy, R. W. Corell, L. Christensen, N. Eckley, J. X. Kasperson, A. Luers, M. L. Martello, C. Polsky, A. Pulsipher, and A. Schiller. 2003. A framework for vulnerability analysis in sustainability science. Proceedings of the National Academy of Sciences of the United States of America 100:80748079.

Turton, C. 2000. Enhancing livelihoods through participatory watershed development in India. Working Paper No. 131 Overseas Development Institute, London, UK.

United States Fish and Wildlife Service. 2009. Big Muddy national wildlife refuge. United States Fish and Wildlife Service, Columbia, Missouri, USA. [online] URL: http://www.fws.gov/midwest/bigmuddy/

von Schirnding, Y. 2005. The world summit on sustainable development: reaffirming the centrality of health. Globalization and Health 1:8.

Walker, B. H., L. H. Gunderson, A. P. Kinzig, C. Folke, S. R. Carpenter, and L. Schultz. 2006. A handful of heuristics and some propositions for understanding resilience in social-ecological 
systems. Ecology and Society 11(1): 13. [online] URL: http://www.ecologyandsociety.org/vol11/iss1/ art13/.

Waltner-Toews, D. 2001. An ecosystem approach to health and its applications to tropical and emerging diseases. Cadernos de Saúde Pública. Reports in Public Health 17:7-36.

Waltner-Toews, D. 2004. Ecosystem sustainability and health: a practical approach. Cambridge University Press, Cambridge, UK.

Waltner-Toews, D. 2009. Food, global environmental change and health: Ecohealth to the rescue? Mc Gill Medical Journal 12:85-89.

Waltner-Toews, D., J. Kay, T. P. Murray, and C. Neudoerffer. 2004. Adaptive methodology for ecosystem sustainability and health (AMESH): an introduction. Page 400 in G. Midgley and A. E. Ochoa-Arias, editors. Community operational research: OR and systems thinking for community development. Springer, New York, New York, USA.

Waltner-Toews, D., and J. J. Kay. 2005. The evolution of an ecosystem approach: the diamond schematic and an adaptive methodology for ecosystem sustainability and health. Ecology and Society 10(1): 38. [Online] URL: http://www.ecolo gyandsociety.org/vol10/iss1/art38/.

Waltner-Toews, D., and E. Wall. 1997. Emergent perplexity: in search of post-normal questions for community and agroecosystem health. Social Science and Medicine 45:1741-1749.

Wernham, A. 2007. Inupiat health and proposed Alaskan oil development: results of the first integrated health impact assessment/environmental impact statement for proposed oil development on alaska's north slope. EcoHealth 4:500-513.

World Health Organization (WHO). 1986. Ottawa charter for health promotion. WHO, Geneva Switzerland.

WHO. 2004. Water, sanitation and hygiene links to health. Facts and figures. WHO, Geneva, Switzerland.
Wilkinson, R., and M. Marmot. 2003. The solid facts. World Health Organization, Copenhagen Denmark.

Woodward, A., S. Hales, and P. Weinstein. 1998. Climate change and human health in the Asia Pacific region: who will be the most vulnerable. Climate Research 11:31-38.

World Bank. 2008. Poverty and the environment: Understanding linkages at the household level. World Bank, Washington, D.C., USA.

World Commission on Dams. 2000. Dams and development: a new frameworkfor decision-making -the report of the World Commission on Dams. Earthscan, London, UK.

Wu, C., C. Maurer, Y. Wang, S. Xue, and D. L. Davis. 1999. Water pollution and human health in China. Environmental Health Perspectives 107:251256.

Zinsstag, J., E. Schelling, K. Wyss, and M. B. Mahamat. 2005. Potential of cooperation between human and animal health to strengthen health systems. The Lancet 366 2142-2145. 